\title{
Generating a Three-Dimensional Genome from Xenopus with Hi-C
}

\author{
Ian K. Quigley ${ }^{1,3}$ and Sven Heinz $z^{2,4}$ \\ ${ }^{1}$ Molecular Neurobiology Lab, Salk Institute for Biological Studies, La Jolla, California 92037; ${ }^{2}$ Department of \\ Medicine, University of California, San Diego, San Diego, California 92093
}

\section{MATERIALS}

Hi-C is a sequencing-based method that captures three-dimensional (3-D) genome interactions by counting the interaction frequencies of pairs of genomic loci. This protocol describes the application of in situ Hi-C to the Xenopus embryo. Briefly, after fixing embryos with formaldehyde, nuclei are isolated and chromatin is digested with a restriction enzyme. Restriction sites are filled in with a biotinylated nucleotide and the blunted ends are re-ligated in place, all while still contained in the nuclei (i.e., in situ). Subsequently, the re-ligated genomic DNA is isolated and fragmented by sonication. Biotinylated ligation junctions are captured with streptavidin-coated beads, and DNA fragments are amplified by ligation-mediated polymerase chain reaction (LM-PCR). The PCR product is isolated and sequenced from both ends (paired-end), and informatics methods are then applied to align the two sides of the ligation junctions to the reference genome. Because ligation occurs much more frequently intra- than interchromosomally, and with generally decreasing frequency the further away DNA loci are from each other on the linear chromosome, interaction frequency information can be used to assist in assembling genomes and to phase haplotypes, which is especially useful in the case of a tetraploid organism such as X. laevis. Our streamlined version of in situ Hi-C was optimized for high throughput and low cost, and enables generation of high-quality Hi-C libraries from small cell numbers (down to $\sim 10,000$ cells) in $2 \mathrm{~d}$.

It is essential that you consult the appropriate Material Safety Data Sheets and your institution's Environmental Health and Safety Office for proper handling of equipment and hazardous materials used in this protocol.

RECIPES: Please see the end of this protocol for recipes indicated by $<R>$. Additional recipes can be found online at http://cshprotocols.cshlp.org/site/recipes.

Reagents

Agarose gel (low EEO; e.g., Seakem LE) (2\% in TBE)

Biotin-14-dATP (0.4 mM) (Invitrogen 19524016)

Bovine serum albumin (BSA) $(10 \%[\mathrm{v} / \mathrm{v}])$

BW (bind \& wash) buffer $(2 \times)<$ R $>$

BWT (bind \& wash \& Tween) buffer $(2 \times)<\mathrm{R}>$

BWT100 (bind \& wash \& Triton X-100) buffer $(1 \times)<$ R $>$

Chloroform

ClaI (10 U/ $\mu$ L) (New England BioLabs R0197S) and 10× CutSmart buffer (optional; see Step 89)

Deoxynucleotide solution set (dATP/dCTP/dGTP/dTTP; 100 mm each) (New England BioLabs

N0446S)

\footnotetext{
${ }^{3}$ Present address: Recursion Pharmaceuticals, Salt Lake City, Utah 84101.

${ }^{4}$ Correspondence: sheinz@ucsd.edu

From the Xenopus collection, edited by Hazel L. Sive.

(c) 2019 Cold Spring Harbor Laboratory Press

Cite this protocol as Cold Spring Harb Protoc; doi:10.1101/pdb.prot098343
} 
I.K. Quigley and S. Heinz

DNA isolation buffer $<\mathrm{R}>$ (optional; see Step 82 )

Dynabeads MyOne Streptavidin T1 (Invitrogen 65601)

EDTA $(0.5 \mathrm{M}, \mathrm{pH} 8.0)$

Ethanol $(80 \%, 100 \%)$

Formaldehyde (16\%, EM grade [e.g., Pierce 28906] or 37\%, methanol-stabilized [e.g., Sigma-Aldrich F8775])

GelGreen (Biotium) and/or SYBR Gold (Thermo)

Glycine (2.625 M)

GlycoBlue coprecipitant $(15 \mu \mathrm{g} / \mu \mathrm{L})$ (Invitrogen AM9515)

Klenow fragment $(5 \mathrm{U} / \mu \mathrm{L})$ (Enzymatics P7060L)

Klenow fragment $\left(3^{\prime} \rightarrow 5^{\prime}\right.$ exo-) $(5 \mathrm{U} / \mu \mathrm{L})$ (Enzymatics P7010-LC-L)

Loading dye $(12 \times)$ (e.g., $60 \%$ glycerol $/ 0.05 \%$ xylene cyanol/ $/ 0.05 \%$ Orange $G$ )

Lysis buffer for Xenopus Hi-C $<\mathrm{R}>$

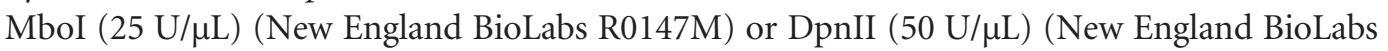
$\mathrm{R} 0543 \mathrm{~T} / \mathrm{M})$

$\mathrm{NaCl}(5 \mathrm{M})$

NEBuffer 2 (10×) (New England BioLabs B7002S)

NEXTflex DNA barcodes (Bioo Scientific 514104)

PCR master mix (NEBNext Ultra II Q5) (New England Biolabs M0544S)

PEG $(20 \%) / 1.5 \mathrm{M} \mathrm{NaCl}<\mathrm{R}>$ (optional; see Step 84 )

PEG $(20 \%) / 2.5 \mathrm{M} \mathrm{NaCl}<\mathrm{R}>$

Phenol:chloroform:isoamyl alcohol (25:24:1 [v/v]) (Invitrogen 15593049)

Phosphate-buffered saline (PBS)

Proteinase K $(20 \mu \mathrm{g} / \mu \mathrm{L})$ (Invitrogen AM2546)

Qubit dsDNA HS Assay Kit (Invitrogen Q32854)

RNase A (DNase-free) $(10 \mu \mathrm{g} / \mu \mathrm{L})$

SDS $(10 \%[\mathrm{v} / \mathrm{v}])$

Sera-Mag SpeedBeads (carboxylate-modified magnetic particles), hydrophobic (GE Healthcare Life

Sciences 65152105050250)

Solexa 1GA primer: $5^{\prime}$-AATGATACGGCGACCACCGA-3' (10 $\mu \mathrm{m}$ in TE buffer)

Solexa 1GB primer: $5^{\prime}$-CAAGCAGAAGACGGCATACGA-3' (10 $\mu \mathrm{m}$ in TE buffer)

T4 DNA ligase (rapid) $(600 \mathrm{U} / \mu \mathrm{L})$, with $2 \times$ rapid ligation buffer (Enzymatics L6030-HC-L)

T4 DNA ligase buffer $(10 \times)$

T4 DNA polymerase (3 U/ $\mu \mathrm{L})$ (Enzymatics P7080L)

T4 polynucleotide kinase (10 U/ $\mu \mathrm{L})$ (Enzymatics Y9040L)

TET buffer $<$ R $>$

Triton X-100 (10\% [v/v])

Trypan blue (optional; see Step 10)

TT buffer $<$ R $>$

TTLoE buffer $<\mathrm{R}>$

Tween $20(10 \%[\mathrm{v} / \mathrm{v}])$

Xenopus laevis ( $\sim 100$ dejellied embryos [stage 10.5] or animal caps [stage 18]) (Ariizumi et al. 2009;

Sive et al. 2010)

Equipment

Agarose gel electrophoresis system (e.g., Labnet International ENDURO Gel XL electrophoresis system with $4-\mu \mathrm{L}$ well-size combs)

Centrifuge (refrigerated tabletop) with swing buckets for 96-well plates (e.g., Eppendorf 5810R)

Centrifuge (refrigerated tabletop) for microcentrifuge tubes (e.g., Eppendorf 5424R)

Hybridization oven or heat block (s) at $37^{\circ} \mathrm{C}, 55^{\circ} \mathrm{C}$, and $65^{\circ} \mathrm{C}$

Liquid nitrogen or dry ice/methanol slurry 
Microcentrifuge tubes (1.5- and 2.0-mL, polypropylene)

Microcentrifuge tubes (1.5-mL) (LoBind DNA) (Eppendorf 30108051)

Microcentrifuge tubes (2.0-mL) (Axygen MAXYmum Recovery) (Corning MCT-200-L)

Microscope and hemocytometer (optional; see Step 10)

microTUBE (AFA fiber preslit snap-cap) (Covaris 520045)

PCR 8-tube strips (0.2-mL) with 8-cap strips (USA Scientific 1402-2700)

PCR tube rack (Axygen) (Corning R-96-PCR-FSP)

Qubit fluorometer (Invitrogen Q33216) and assay tubes (Axygen PCR-05-C)

Rotator (e.g., Thermo Scientific HulaMixer) at $16^{\circ} \mathrm{C}$ and $37^{\circ} \mathrm{C}$

Side-skirted magnet (DynaMag-96) (Invitrogen 12027)

Sonicator (e.g., Covaris Focused-Ultrasonicator M220)

TapeStation or BioAnalyzer (optional; see Steps 43, 76, and 88)

Thermal cycler with $100 \mu \mathrm{L}$ capacity (e.g., Bio-Rad T100)

Tissue grinder, Dounce (2-mL) (Kimble 885300-0002) (optional; see Step 4)

Transilluminator (UV or non-UV, e.g., Clair Chemicals Dark Reader DR22A) and smartphone or gel documentation system

Vacuum aspirator (manifold for PCR tube strips) (BrandTech 704526)

Use with filterless $10-\mu \mathrm{L}$ tips.

Vortex

\section{METHOD}

There are a number of experimental variations on generating sequencing libraries that capture 3D interactions via proximity ligation (Mishra and Hawkins 2017), all based on the original chromosome conformation capture protocol (3C) (Dekker et al. 2002) and its genome-wide adaptation, Hi-C (Lieberman-Aiden et al. 2009). Here, we describe the application of one of the easier-to-perform protocols for capturing 3-D genome interactions, in situ Hi-C (Rao et al. 2014). This protocol has proven to be exceptionally robust. To date, we have used it to generate several hundred highquality libraries in different conditions and species. In the handful of instances where the protocol failed, it did not yield a library at all, e.g., in species with extreme GC content, or in apoptotic cells.

\section{Fixing and Storing Embryos}

The protocol works well with $5 \times 10^{4}$ to $1.5 \times 10^{6}$ cells, and we have had success making libraries with as little as 12,000 cells. For a first attempt, starting with at least $10^{5}$ cells is recommended. This number of nuclei is easy to see during the different steps, which prevents accidental sample loss.

1. Transfer Xenopus embryos to a 2 -mL microcentrifuge tube containing $1 \mathrm{~mL} 1 \%$ formaldehyde in PBS. Fill the tube to the top with $1 \%$ formaldehyde in PBS, and fix the embryos for 30 min at room temperature on a rotating platform.

The number of caps or embryos used here should occupy a 2-mL microcentrifuge tube; top off the tube with the formaldehyde solution in this step.

2. Remove the formaldehyde and quench the fixative by washing once for $10 \mathrm{~min}$ with $0.125 \mathrm{M}$ glycine in PBS.

3. Wash the embryos three times for 5 min per wash in ice-cold PBS. Remove the PBS and flashfreeze the pellet in a dry ice/methanol slurry or liquid nitrogen. Store at $-80^{\circ} \mathrm{C}$.

Fixed cells are extraordinarily stable. We have successfully performed Hi-C on murine cells 5 yr after fixation.

Isolating Nuclei

Use filter tips for all pipetting steps to prevent adding $500 \mu \mathrm{L}$ room-temperature lysis buffer and cross-contamination between samples and experiments.

4. Dissociate the embryonic tissue by pipetting rapidly with a 1-mL pipette tip.

Alternatively, grind the tissue in a 2-mL Dounce tissue grinder with 10 strokes of a loose (A) pestle. 
I.K. Quigley and S. Heinz

5. After using a Dounce homogenizer, transfer the homogenate to a 2-mL microcentrifuge tube. Centrifuge at $2500 \mathrm{~g}$ for $5 \mathrm{~min}$ at room temperature.

The supernatant will have a fat layer on top, which will be subsequently removed by blotting with Kimwipes and two rounds of washes.

6. Remove as much of the top fat layer as possible by blotting with a Kimwipe, and then carefully aspirate most of the supernatant, leaving the nuclear/plasma protein pellet intact.

7. To lyse the cells, resuspend the pellet by pipetting with $1 \mathrm{~mL}$ of Lysis Buffer at room temperature.

8. To isolate the nuclei, centrifuge the sample at $2500 \mathrm{~g}$ for $5 \mathrm{~min}$ at room temperature. Blot off the fat layer on top and discard the supernatant.

9. Repeat Steps 7 and 8 to wash the nuclei and remove debris.

Incubating fixed cells with lysis buffer containing only sodium dodecyl sulfate (SDS) lyses the cytoplasmic membrane and strips cytoplasmic proteins but leaves the nuclei intact, likely a result of formaldehyde fixation of the nuclear lamina (Nickerson et al. 1997). We found the initial nonionic detergent washes that precede SDS lysis in common Hi-C protocols to be unnecessary.

10. (Optional) Check/count the nuclei under a microscope: After resuspending the nuclei in lysis buffer in Step 9, mix $20 \mu \mathrm{L}$ of the nuclei suspension with an equal amount of $0.4 \%$ Trypan Blue and count the dark-blue nuclei on a hemocytometer.

In our hands, this procedure produces roughly 4000-5000 nuclei per embryo at stage 10.5 or per animal cap at stage 18 .

11. After the last wash is complete, remove as much of the supernatant as possible and resuspend the nuclei in $200 \mu \mathrm{L}$ of lysis buffer.

12. Transfer the suspension to an eight-well PCR tube strip and complete lysis by incubating for 7 min at $62^{\circ} \mathrm{C}$ in a thermal cycler.

SDS and elevated temperature make restriction sites more accessible by solubilizing non-cross-linked proteins and partially reversing protein-DNA cross-links.

13. (Optional) As an Input Control, transfer $8 \mu \mathrm{L}$ (4\%) of the well-resuspended sample to a separate 0.2-mL PCR tube.

When using a low number of cells, the DNA content will be difficult or impossible to detect on an ethidium bromide- or even GelGreen-stained agarose gel. For example, if $10^{5}$ cells are used for an experiment, the $4 \%$ Input Control sample will at best contain 27 ng of DNA.

14. Centrifuge the PCR tube strip containing the nuclei at $2500 \mathrm{~g}$ for $5 \mathrm{~min}$ at room temperature in a tabletop centrifuge with swing buckets for 96-well plates. Discard most of the supernatant (at a minimum $190 \mu \mathrm{L}$ [or $182 \mu \mathrm{L}$ if the optional Input Control was set aside]), leaving the nuclei in a small volume $(\sim 10 \mu \mathrm{L})$ of $\mathrm{L} 2$ buffer.

Digesting Chromatin

15. Resuspend the nuclei in digestion buffer $(25 \mu \mathrm{L} 10 \%$ Triton X-100, $25 \mu \mathrm{L} 10 \times$ NEBuffer $2,195 \mu \mathrm{L}$ $\mathrm{H}_{2} \mathrm{O}$ ) and rotate for $15 \mathrm{~min}$ at $37^{\circ} \mathrm{C}$ to dilute and sequester the remaining SDS.

16. Add $4 \mu \mathrm{L}$ of $\mathrm{MboI}$ restriction enzyme $(25 \mathrm{U} / \mu \mathrm{L})$ and incubate for $3 \mathrm{~h}$ up to overnight at $37^{\circ} \mathrm{C}$ on a rotating platform at 8 RPM.

Other four-cutter restriction enzymes have been used (e.g., DpnII, HaellI), and depending on their recognition motif produce different coverage biases (Liang et al. 2017). If employing Dpnll instead of Mbol, use the dedicated Dpnll buffer and $2 \mu \mathrm{L}$ of the high-concentration enzyme $(50 \mathrm{U} / \mu \mathrm{L})$. For previously untried enzymes, test their efficiency on a PCR product before using them in $\mathrm{Hi}-\mathrm{C}$, to ensure that they are not inhibited by the presence of the detergents used in this reaction.

17. Inactivate the restriction digest for $20 \mathrm{~min}$ at $62^{\circ} \mathrm{C}$ in a thermal cycler, and then cool to room temperature.

For Dpnll and Mbol, omitting this heat inactivation step does not affect the Hi-C results. Both enzymes are inhibited by Dam methylation of their recognition motif. The fill-in reaction with N6-Biotin-14-dATP in the next section mimics Dam hemi-methylation and inhibits digestion of the reconstituted GATC site. This was confirmed for Dpnll with a dsDNA oligonucleotide containing a central single-stranded GATC site. Fill-in 
Filling in and Biotinylating Restriction Overhangs

21. To fill in the GATC overhangs generated by MboI cleavage, prepare a $2 \times$ Fill-In Master Mix of the following reagents on ice.

with N6-Biotin-14-dATP (i.e., hemi-modification) blocked Dpnll digestion similar to N6-Methyl-dATP hemimethylation (data not shown).

18. (Optional) As a Digestion Control, transfer $12 \mu \mathrm{L}$ (4.8\%) of the well-resuspended sample to a 0.2-mL PCR tube.

With $10^{5}$ cells of starting material, the Digestion Control can contain up to $31 \mathrm{ng}$ of DNA.

19. Collect the nuclei by centrifugation at $500 \mathrm{~g}$ for $5 \mathrm{~min}$ at room temperature in a tabletop centrifuge with swing buckets for 96-well plates.

20. Discard $200 \mu \mathrm{L}$ (188 $\mu \mathrm{L}$ if Digestion Control was set aside) of the supernatant, leaving the nuclei in a $\sim 50-\mu \mathrm{L}$ volume.

\begin{tabular}{lrc}
\hline Reagent & Amount per reaction & Final concentration \\
\hline $\mathrm{ddH}_{2} \mathrm{O}$ & $31.95 \mu \mathrm{L}$ & \\
$\mathrm{NEB} 2(10 \times)$ & $5 \mu \mathrm{L}$ & $1 \times$ \\
$\mathrm{dCTP}(10 \mathrm{~mm})$ & $0.35 \mu \mathrm{L}$ & $35 \mu \mathrm{M}$ \\
$\mathrm{dTTP}(10 \mathrm{~mm})$ & $0.35 \mu \mathrm{L}$ & $35 \mu \mathrm{M}$ \\
$\mathrm{dGTP}(10 \mathrm{mM})$ & $0.35 \mu \mathrm{L}$ & $35 \mu \mathrm{M}$ \\
Biotin-14-dATP $(0.4 \mathrm{~mm})$ & $7.5 \mu \mathrm{L}$ & $30 \mu \mathrm{M}$ \\
Triton X-100 $(10 \%)$ & $2 \mu \mathrm{L}$ & $0.2 \%$ \\
Klenow fragment $(5 \mathrm{U} / \mu \mathrm{L})$ & $2.5 \mu \mathrm{L}$ & $12.5 \mathrm{U}$ \\
Total volume & $50 \mu \mathrm{L}$ &
\end{tabular}

22. Add $50 \mu \mathrm{L}$ of $2 \times$ Fill-In Master Mix to each sample tube from Step 20. Rotate the fill-in reactions for $40 \mathrm{~min}$ at room temperature $\left(22^{\circ} \mathrm{C}-24^{\circ} \mathrm{C}\right)$.

The lower Biotin-14-dATP concentration compared to the original protocol is offset by incubation at lower temperature, which yields similarly high-quality libraries and reduces cost. Biotin-14-dCTP may also be used but in our hands produces lower yields.

In the meantime, prepare Ligation Mix 1 (see Step 24) on ice.

23. Place the reactions on ice.

(Optional) Collecting the nuclei and discarding most of the supernatant (as in Step 19) might further decrease the amount of free DNA that contributes to noninformative reads. In this case, replace the discarded supernatant with an equal volume of $1 \times$ NEBuffer 2.

Performing Proximity Ligation

24. To prepare Ligation Mix 1, combine the following reagents on ice and mix. For each sample, transfer $400 \mu \mathrm{L}$ Ligation Mix 1 into a LoBind 1.5-mL microcentrifuge tube.

\begin{tabular}{lcc}
\hline Reagent & Amount per reaction & Final concentration \\
\hline $\mathrm{ddH}_{2} \mathrm{O}$ & $322.5 \mu \mathrm{L}$ & \\
T4 DNA ligase buffer $(10 \times)$ & $40 \mu \mathrm{L}$ & $1 \times$ \\
Triton X-100 $(10 \%)$ & $36 \mu \mathrm{L}$ & $0.72 \%$ \\
BSA $(10 \%)$ & $0.5 \mu \mathrm{L}$ & $0.01 \%$ \\
T4 DNA ligase $(600 \mathrm{U} / \mu \mathrm{L})$ & $1 \mu \mathrm{L}$ & $600 \mathrm{U}$ \\
Total volume & $400 \mu \mathrm{L}$ & \\
\hline
\end{tabular}

25. Transfer each sample $(100 \mu \mathrm{L})$ to a separate LoBind tube containing Ligation Mix 1 (final volume: $500 \mu \mathrm{L}$ ). Rotate at $8 \mathrm{rpm}$ for $4 \mathrm{~h}$ to overnight at $16^{\circ} \mathrm{C}$.

26. Stop the proximity ligation reactions by adding $20 \mu \mathrm{L}$ of $0.5 \mathrm{M}$ EDTA (a $2 \times$ molar excess over $\left.10 \mathrm{~mm} \mathrm{Mg}^{2+}\right)$. 
I.K. Quigley and S. Heinz

Reversing Cross-Links and Purifying DNA

The purification described in Steps 30-37 is required to clean the biotinylated fragments.

27. Add $1 \mu \mathrm{L}$ of RNase $\mathrm{A}(10 \mu \mathrm{g} / \mu \mathrm{L})$ to each reaction. Incubate for $15 \mathrm{~min}$ at $37^{\circ} \mathrm{C}$.

28. Add $33 \mu \mathrm{L}$ of $5 \mathrm{M} \mathrm{NaCl}$ and $55 \mu \mathrm{L}$ of $10 \%$ SDS to each reaction. Incubate overnight at $65^{\circ} \mathrm{C}$ in a hybridization oven or heat block to reverse cross-links.

29. Add $10 \mu \mathrm{L}$ of proteinase $\mathrm{K}(20 \mu \mathrm{g} / \mu \mathrm{L})$ to each reaction. Incubate for $90 \mathrm{~min}$ at $55^{\circ} \mathrm{C}$ followed by for $30 \mathrm{~min}$ at $65^{\circ} \mathrm{C}$.

30. Extract each reaction once with $600 \mu \mathrm{L}$ of phenol:chloroform:isoamyl alcohol (25:24:1 [v/v]), mixing vigorously by hand or by vortexing. Centrifuge the samples at full speed in a microcentrifuge $(>15,000 \mathrm{~g})$ for $5 \mathrm{~min}$ at room temperature.

31. Transfer each DNA-containing upper (aqueous) phase to a fresh $1.5-\mathrm{mL}$ tube.

32. Extract residual phenol from the DNA-containing supernatants by adding $300 \mu \mathrm{L}$ of chloroform to each sample. Mix vigorously as above and centrifuge at full speed $(>15,000 \mathrm{~g})$ for $1 \mathrm{~min}$ at room temperature.

33. Transfer the DNA-containing upper phase to a 2-mL MAXYmum Recovery tube.

The cylindrical shape of the bottom of these tubes helps collect the DNA in an easily visible pellet in the next steps.

34. Add 1.5 $\mu \mathrm{L}$ of GlycoBlue to each sample. Precipitate the DNA with $1400 \mu \mathrm{L}$ of $100 \% \mathrm{EtOH}$.

35. Centrifuge at $15,000 \mathrm{~g}$ for $20 \mathrm{~min}$ at $4^{\circ} \mathrm{C}$ to pellet the DNA. Discard the supernatant.

36. Wash each DNA pellet once with $1 \mathrm{~mL}$ of $80 \% \mathrm{EtOH}$. Centrifuge at $8000 \mathrm{~g}$ for $5 \mathrm{~min}$ at $4^{\circ} \mathrm{C}$.

37. Discard the supernatant and air-dry the DNA pellet.

"Dangling" ends that are biotinylated but did not ligate to anything typically make up $1 \%-5 \%$ of the sequencing reads in an in situ Hi-C library. The biotin can be removed from these ends by treating the DNA with T4 DNA polymerase, which has a strong 3'-5' exonuclease activity, to prevent their binding to streptavidin beads in the next steps. Exonuclease treatment is performed at low temperature and in the presence of dGTP and dATP to prevent complete digestion of all DNA. A detailed protocol for biotin removal from unligated ends can be found in Belaghzal et al. (2017). In our hands, T4 DNA polymerase treatment reduces dangling ends by $50 \%$ to $0.5 \%-2.5 \%$ of the total while reducing the total DNA amount by up to $60 \%$. Therefore, we typically do not digest dangling ends before streptavidin capture of biotinylated DNA.

38. Dissolve each DNA pellet in $131 \mu \mathrm{L}$ of TT buffer.

Following DNA isolation, the use of Tween 20 or Triton X-100 in all buffers prevents sample loss due to DNA adsorption to the tube wall, even at very low $(<1 \mathrm{pg} / \mu \mathrm{L})$ DNA concentrations.

39. (Optional) As a Pre-Sonication Control, transfer $5 \mu \mathrm{L}$ of each DNA solution to a separate $0.2-\mathrm{mL}$ PCR tube. Make up the missing volume in the original sample with an extra $5 \mu \mathrm{L}$ of TT buffer.

40. Measure the DNA concentration of $1 \mu \mathrm{L}$ of the DNA solution, e.g., using a Qubit fluorometer.

The amount of recovered DNA will be slightly lower than $6.8 \mathrm{pg} /$ nucleus in the starting material.

Shearing and Immobilizing DNA

\section{Shearing DNA}

41. Transfer up to $800 \mathrm{ng}$ of DNA in a total volume of $130 \mu \mathrm{L}$ of TT buffer to a Covaris microTUBE. The DNA amount of $800 \mathrm{ng}$ represents an upper bound; this protocol has generated high-quality data from as little as $80 \mathrm{ng}$ of DNA (equivalent to $\sim 12,000$ cells).

42. Shear the DNA to a 300-bp average size in a Covaris Focused-ultrasonicator using the manufacturer-provided settings for shearing DNA to $300 \mathrm{bp}$ and the required accessories for DNA shearing in $130 \mu \mathrm{L}$ microTubes. (For Covaris M220/S220\&E220, use Peak Incident Power 50/140 W, Duty Factor 20/10\%, Cycles per Burst 200/200, Treatment Time 65/80 sec; see https://covaris.com/resources/protocols/dna-shearing-protocols/). 
If a Covaris sonicator is unavailable, other water bath or probe sonicators (e.g., Diagenode Bioruptor, Branson Ultrasonics S-250, QSonica Q800, Active Motif EpiShear) can be used to shear the DNA to a 300-bp average size. Sonication conditions can be optimized by shearing RNA-free genomic DNA in TT buffer for increasing amounts of time and checking size on an agarose gel. DNA sonication efficiency is relatively independent of concentration. For example, a $10-\mu \mathrm{g} / \mathrm{mL}$ genomic DNA stock in TT buffer can be used for protocol optimization.

For probe sonicators, the minimum volume that can easily be sheared without splashing using a 1/8 inch tip in a 1.5-mL microcentrifuge tube is $200 \mu \mathrm{L}$. This requires inserting the tip into the tube with $\sim 2 \mathrm{~mm}$ of clearance to the tube bottom, and mounting the tube with a clamp to the sonicator stand such that the tip does not touch the tube wall. For many sonicators, optimization protocols and approximate sonication conditions are published (e.g., http://www.activemotif.com/documents/1746.pdf). Importantly, probe sonicator tips erode with continued use, leading to decreased sonication efficiency. This means that compared to a new tip, more sonication cycles will be needed to yield the same results, which needs to be considered when relying on published protocols.

As an example, to optimize conditions for a probe sonicator with a 1/8-inch-wide tip, make up $250 \mu \mathrm{L}$ of TT buffer containing $2.5 \mu \mathrm{g}$ of genomic DNA in a 1.5-mL LoBind microcentrifuge tube. Mount the tube to the post of the sonicator stand using a small clamp, such that the sonicator tip is immersed in the liquid with $\sim 2 \mathrm{~mm}$ of clearance from the tube bottom (placing the tip much higher than that will lead to splashing and sample loss). Immerse the tube in a wet-ice slurry in a 100-mL plastic beaker, deep enough to reach above the top of the liquid in the tube. Sonicate the sample for 5, 10, and 15 cycles of $10 \mathrm{sec}$ on, $30 \mathrm{sec}$ off (e.g., at $25 \%$ duty or 5-10 W output; low enough to not splash, but high enough to sonicate the DNA). Take off $15 \mu \mathrm{L}$ (150 ng of DNA) every five cycles, and run directly on a $1 \times$ GelGreen-containing $2 \%$ agarose/TBE gel, next to a 1-kb Plus ladder. For Hi-C, use a setting that gives a 300-bp average fragment size.

43. (Optional) Determine the average fragment size on a $2 \%$ agarose/TBE gel containing GelGreen or SYBR Gold, or on a TapeStation or BioAnalyzer. Alternatively, keep $5 \mu \mathrm{L}$ of DNA solution in a separate 0.2 -mL PCR tube as a Post-Sonication Control for later testing, and make up the missing volume with an extra $5 \mu \mathrm{L}$ of TT buffer.

Size estimation before library prep may require unacceptable amounts of material when using very low amounts of starting material. In this case, the Test PCR (Steps 60-64) after library prep will provide a first estimate of library concentration and size distribution.

If testing low amounts of DNA at this stage, we highly recommend using a TapeStation or BioAnalyzer with high-sensitivity reagents, or a DNA dye that is more sensitive than ethidium bromide, such as GelGreen ( $23 \mathrm{ng}$ detection limit for a 300-bp average size DNA smear in a prestained $2 \%$ agarose/TBE gel) or SYBR Gold.

\section{Equilibrating Streptavidin Beads}

44. Per reaction, transfer $20 \mu \mathrm{L}$ of Dynabeads MyOne Streptavidin T1 bead suspension to a $1.5-\mathrm{mL}$ microcentrifuge tube (up to $300 \mu \mathrm{L}$ total; ensure that beads are thoroughly resuspended before use). Collect beads on a magnet and discard the supernatant.

45. Wash the beads by resuspending in $1.2 \mathrm{~mL}$ of $1 \times \mathrm{BW}$ buffer. Collect the beads on a magnet and discard the supernatant.

46. Resuspend the beads in $130 \mu \mathrm{L}$ of $2 \times$ BWT buffer per sample (e.g., for 10 samples, resuspend the amount of beads contained in the $200-\mu \mathrm{L}$ volume of the initial bead suspension in $1300 \mu \mathrm{L}$ of $2 \times$ BWT buffer). Distribute 130- $\mu$ L aliquots of the bead suspension into an eight-well PCR tube strip.

\section{Immobilizing Biotinylated DNA on Streptavidin Beads}

47. Add the sonicated DNA $(130 \mu \mathrm{L})$ from the microTUBE to the bead suspension. Bind the DNA to the Dynabeads by rotating overhead (e.g., at $8 \mathrm{RPM}$ ) for $30 \mathrm{~min}$ at room temperature.

In the meantime, prepare the Blunting Mix (see Step 50) on ice.

In our hands, 30\%-40\% of the genomic DNA binds to $20 \mu \mathrm{L}$ of T1 Dynabeads. This fraction decreases if more than $800 \mathrm{ng}$ of DNA are used, indicating that the beads saturate with this amount of DNA. Conversely, lowering the DNA amount below 800 ng does not change the percentage of DNA that binds to the beads, suggesting that only a fraction of the total is labeled with biotin and/or that only a (constant) fraction of the biotinylated DNA fraction binds to the beads. 
I.K. Quigley and S. Heinz

48. Wash away the unbound DNA by collecting the beads on a magnet and discarding the supernatant. Resuspend the beads in $180 \mu \mathrm{L}$ of $1 \times$ BWT100.

49. Rebuffer the sample and dilute the $\mathrm{NaCl}$ by collecting the beads on a magnet, completely aspirating the supernatant, and resuspending the beads in $180 \mu \mathrm{L}$ of TET buffer.

Preparing the Library

\section{Blunting}

50. To prepare the Blunting Mix, combine the following reagents on ice. Collect the DNA-coated beads from Step 49 on a magnet, discard the supernatant and immediately resuspend each sample in $95 \mu \mathrm{L}$ of Blunting Mix. Incubate for $30 \mathrm{~min}$ at $20^{\circ} \mathrm{C}$ in a thermal cycler.

\begin{tabular}{lcc}
\hline Reagent & Amount per reaction & Final concentration \\
\hline $\mathrm{ddH}_{2} \mathrm{O}$ & $76.1 \mu \mathrm{L}$ & \\
T4 DNA ligase buffer $(10 \times)$ & $10 \mu \mathrm{L}$ & $1 \times$ \\
Tween 20 $(10 \%)$ & $0.5 \mu \mathrm{L}$ & $0.05 \%$ \\
dNTP mix $(10 \mathrm{~mm}$ each) & $4 \mu \mathrm{L}$ & $0.4 \mathrm{mM}$ \\
T4 DNA polymerase $(3 \mathrm{U} / \mu \mathrm{L})$ & $2 \mu \mathrm{L}$ & $6 \mathrm{U}$ \\
Klenow fragment $(5 \mathrm{U} / \mu \mathrm{L})$ & $0.4 \mu \mathrm{L}$ & $2 \mathrm{U}$ \\
T4 polynucleotide kinase $(10 \mathrm{U} / \mu \mathrm{L})$ & $2 \mu \mathrm{L}$ & $20 \mathrm{U}$ \\
Total volume & $95 \mu \mathrm{L}$ & \\
\hline
\end{tabular}

51. Stop each reaction by adding $2.5 \mu \mathrm{L}$ of $0.5 \mathrm{~m}$ EDTA.

\section{A-Tailing}

52. Collect the beads on a magnet and discard the supernatant. Wash the beads twice with $150 \mu \mathrm{L}$ of $1 \times$ BWT100 followed by once with $180 \mu \mathrm{L}$ of TET buffer.

53. To prepare the A-Tail Mix, combine the following reagents. Resuspend each bead sample from Step 52 in $50 \mu \mathrm{L}$ A-Tail Mix. Incubate for $30 \mathrm{~min}$ at $37^{\circ} \mathrm{C}$.

\begin{tabular}{lcc}
\hline Reagent & Amount per reaction & Final concentration \\
\hline $\mathrm{ddH}_{2} \mathrm{O}$ & $41.55 \mu \mathrm{L}$ & \\
NEBuffer 2 $(10 \times)$ & $5 \mu \mathrm{L}$ & $1 \times$ \\
Tween $20(10 \%)$ & $0.25 \mu \mathrm{L}$ & $0.05 \%$ \\
dATP $(100 \mathrm{~mm})$ & $0.2 \mu \mathrm{L}$ & $0.4 \mathrm{mM}$ \\
Klenow $\left(3^{\prime} \rightarrow 5^{\prime}\right.$ exo $)(5 \mathrm{U} / \mu \mathrm{L})$ & $3 \mu \mathrm{L}$ & $15 \mathrm{U}$ \\
Total volume & $50 \mu \mathrm{L}$ & \\
\hline
\end{tabular}

In the meantime, prepare Ligation Mix 2 (see Step 54) on ice.

\section{Ligating Adapters}

54. To prepare Ligation Mix 2, combine the following reagents on ice. Collect the beads from Step 53 on a magnet, discard the supernatant, and resuspend the beads in $48 \mu \mathrm{L}$ of ice-cold Ligation Mix 2. Keep on ice.

\begin{tabular}{lcc}
\hline Reagent & Amount per reaction & Final concentration \\
\hline $\mathrm{ddH}_{2} \mathrm{O}$ & $21.5 \mu \mathrm{L}$ & \\
Rapid ligation buffer $(2 \times)$ & $25 \mu \mathrm{L}$ & $1 \times$ \\
Tween $20(10 \%)$ & $0.5 \mu \mathrm{L}$ & $0.1 \%$ \\
T4 DNA ligase, rapid $(600 \mathrm{U} / \mu \mathrm{L})$ & $1 \mu \mathrm{L}$ & $15 \mathrm{U}$ \\
Total volume & $48 \mu \mathrm{L}$ & \\
\hline
\end{tabular}


55. Add $1 \mu \mathrm{L}$ ( $25 \mathrm{pmol})$ of Nextflex DNA barcode adapters to each reaction on ice and mix. Incubate for $20 \mathrm{~min}$ at room temperature.

When using less than $400 \mathrm{ng}$ of DNA to bind to the beads, the amount of adapters can be reduced to $0.5 \mu \mathrm{L}$ and to $0.25 \mu \mathrm{L}$ when using <100 ng of DNA. Using too little adapter will lower the amount of amplifiable library, even if nominally in excess over bound DNA ends, probably because of ligation being less efficient when DNA is bound to beads.

56. Collect the beads on magnet and discard the supernatant.

57. Wash the beads twice in $150 \mu \mathrm{L}$ of $1 \times$ BW buffer by completely resuspending them in buffer each time, collecting them on a magnet, and discarding the supernatant.

58. Wash the beads twice with $180 \mu \mathrm{L}$ of TET buffer by completely resuspending them in buffer each time, collecting them on a magnet, and discarding the supernatant.

59. Resuspend the beads in $32 \mu \mathrm{L}$ of TTLoE buffer. Store at $4^{\circ} \mathrm{C}$.

For long-term storage, the library-loaded beads can be frozen at $-20^{\circ} \mathrm{C}$.

\section{(Optional) Performing Test PCR}

Semiquantitative PCR using $0.5 \mu \mathrm{L}$ of bead suspension (1/64th of the total) at 12, 16, and 20 cycles ( 4000-, 65, 000-, 1,000,000-fold amplification) gives an indication of how well sonication, bead capture and library prep worked, provides an estimate of the size distribution of the library, and can be used to estimate the minimum cycle number to run for the Library PCR (Step 66).

60. Combine the following reagents.

\begin{tabular}{lcc}
\hline Reagent & Amount per 3.3 reactions & Final concentration \\
\hline $\mathrm{ddH}_{2} \mathrm{O}$ & $4.95 \mu \mathrm{L}$ & \\
NEB Ultra II Q5 Master Mix $(2 \times)$ & $8.25 \mu \mathrm{L}$ & $1 \times$ \\
Solexa 1GA primer $(10 \mu \mathrm{M})$ & $0.825 \mu \mathrm{L}$ & $0.5 \mu \mathrm{M}$ \\
Solexa 1GB primer $(10 \mu \mathrm{M})$ & $0.825 \mu \mathrm{L}$ & $0.5 \mu \mathrm{M}$ \\
Total volume & $14.85 \mu \mathrm{L}$ & \\
\hline
\end{tabular}

61. Thoroughly resuspend the library beads from Step 59. Add $1.65 \mu \mathrm{L}$ of the bead suspension to $14.85 \mu \mathrm{L}$ of Test PCR mix. Mix briefly by vortexing, and then distribute $5 \mu \mathrm{L}$ of the reaction mix into three different $0.2-\mathrm{mL}$ PCR tubes or tube strips.

62. Amplify the library using a thermal cycler as follows: $30 \mathrm{sec}$ at $98^{\circ} \mathrm{C} ; 12,16$, or 20 cycles of $[10 \mathrm{sec}$ at $98^{\circ} \mathrm{C}, 20 \mathrm{sec}$ at $60^{\circ} \mathrm{C}$, and $30 \mathrm{sec}$ at $\left.72^{\circ} \mathrm{C}\right] ; 5 \mathrm{~min}$ at $72^{\circ} \mathrm{C}$; cool to $4^{\circ} \mathrm{C}$. Pause the cycler at the end of the $72^{\circ} \mathrm{C}$ extension step after 12,16 , or 20 cycles and remove a tube strip, or run the tube strips in different cycler blocks.

63. Add $0.5 \mu \mathrm{L}$ of $12 \times$ Loading Dye (e.g., $60 \%$ glycerol $/ 0.05 \%$ xylene cyanol $/ 0.05 \%$ Orange $\mathrm{G}$ ) to each sample and mix. Collect the library beads on a magnet.

64. Electrophorese the supernatant on a 2\% agarose/TBE gel containing $1 \times$ GelGreen.

The lowest cycle number at which a product can be detected as a prominent smear by GelGreen in the Test PCR can be used to determine the appropriate number of PCR cycles for the Library PCR. When using $10 \mu \mathrm{L}(1 / 3)$ of the remaining library for amplification, this volume contains 20-fold more beads than the Test PCR, which is equivalent to around four fewer cycles to obtain similar levels of PCR product.

The expected average library size is 300 bp insert size +125 bp adapter size $=425$ bp. If very low input DNA amounts are used (<100 ng), an adapter dimer band at $125 \mathrm{bp}$ might appear in the Test PCR product. Adapter dimers are problematic for sequencing because they generate noninformative reads and if present at high concentrations can jeopardize the sequencing run. The final PCR cleanup employs polyethylene glycol (PEG) precipitation to size-select against adapter dimers.

See Troubleshooting. 
I.K. Quigley and S. Heinz

\section{Amplifying the Library}

In our hands, one-third (10 $\mu \mathrm{L}$ ) of the library-containing bead suspension from 100,000 nuclei of starting material in a $50-\mu \mathrm{L}$ PCR reaction can yield up to $1 \mu \mathrm{g}$ of library amplicon after 12 cycles.

65. Combine the following reagents.

\begin{tabular}{lcc}
\hline Reagent & Amount per reaction & Final concentration \\
\hline $\mathrm{ddH}_{2} \mathrm{O}$ & $10 \mu \mathrm{L}$ & \\
NEB Ultra II Q5 Master Mix $(2 \times)$ & $25 \mu \mathrm{L}$ & $1 \times$ \\
Solexa 1GA primer $(10 \mu \mathrm{M})$ & $2.5 \mu \mathrm{L}$ & $0.5 \mu \mathrm{M}$ \\
Solexa 1GB primer $(10 \mu \mathrm{M})$ & $2.5 \mu \mathrm{L}$ & $0.5 \mu \mathrm{M}$ \\
DNA-bound bead suspension & $10 \mu \mathrm{L}$ & \\
Total volume & $50 \mu \mathrm{L}$ & \\
\hline
\end{tabular}

66. Amplify the library for four fewer cycles than the lowest cycle number for which a product was observed in the Test PCR; alternatively, amplify for 12 cycles: $30 \mathrm{sec}$ at $98^{\circ} \mathrm{C} ; 12$ cycles (or cycle number for visible Test PCR result-4 cycles) of $\left[10 \mathrm{sec}\right.$ at $98^{\circ} \mathrm{C}, 20 \mathrm{sec}$ at $60^{\circ} \mathrm{C}$, and $30 \mathrm{sec}$ at $\left.72^{\circ} \mathrm{C}\right] ; 5$ min at $72^{\circ} \mathrm{C}$; cool to $4^{\circ} \mathrm{C}$.

\section{Performing DNA Cleanup}

67. Place each PCR reaction tube in an Axygen PCR tube rack on a side-skirted 96-well magnet to collect the Dynabeads on the side of the tube. Transfer $49 \mu \mathrm{L}$ of the supernatant to a new PCR tube strip that contains $2 \mu \mathrm{L}$ of Sera-Mag SpeedBead suspension (unwashed, i.e., in $\mathrm{ddH}_{2} \mathrm{O}$ ) and $38 \mu \mathrm{L}$ of $20 \% \mathrm{PEG} / 2.5 \mathrm{~mm} \mathrm{NaCl}$ (final concentration, 8.5\% PEG).

68. Close the tubes and mix thoroughly by vortexing for $10 \mathrm{sec}$. Centrifuge briefly and then incubate for $10 \mathrm{~min}$ at room temperature.

69. Collect the beads on a magnet for $\sim 2$ min and then discard supernatant with a pipette.

70. Wash the beads by adding $180 \mu \mathrm{L}$ of $80 \% \mathrm{EtOH}$ and sliding the rack and tubes back and forth between the magnets six times, causing the beads to "zip through" the solution from side to side.

71. Collect the beads on a magnet and aspirate the supernatant with a vacuum aspirator.

72. Wash the beads once more with $80 \% \mathrm{EtOH}$ as in Step 70. Collect the beads and aspirate the supernatant for $30 \mathrm{sec}$, effectively air-drying the beads.

73. Allow the beads to further air-dry until cracks appear in the bead pellet.

74. Elute the DNA from the beads by resuspending them in $20 \mu \mathrm{L}$ of TT buffer.

Libraries can be frozen and stored at $-20^{\circ} \mathrm{C}$ with SpeedBeads in the tubes. In this case, avoid bead carryover by placing the samples on a magnet before retrieving DNA.

75. (Optional) Collect the beads on a magnet and transfer the library-containing supernatant to a new PCR tube strip.

76. Measure the DNA concentration by Qubit using the HS DNA assay, and determine the average library size on a $2 \%$ agarose/TBE gel, TapeStation, or BioAnalyzer.

See Troubleshooting.

77. Proceed to high-throughput paired-end sequencing of the final library, or perform optional size selection (Steps 78-81) before sequencing.

See Discussion.

\section{(Optional) Size-Selecting by Double-PEG Precipitation}

Exact size selection of the libraries is generally unnecessary, since the 8.5\% PEG precipitation (Step 67) selects against small inserts, the Covaris sonication reproducibly yields a well-defined, tight size range, and the PCR and sequencing 
procedure itself selects against large inserts. Additionally, size selection incurs a sample loss in the desired size range that should be avoided when using very low amounts of input material. Should size selection be desired, libraries can be size-selected to 250-450 bp either by gel extraction or by differential cleanup with different concentrations of PEG 8000 .

78. For double-Speedbead size selection, first bind large (>350 bp) DNA fragments to SpeedBeads with 7\% PEG: Add $5 \mu \mathrm{L}$ of SpeedBead suspension and $29 \mu \mathrm{L}$ of $20 \% \mathrm{PEG} / 2.5 \mathrm{M} \mathrm{NaCl}$ to $49 \mu \mathrm{L}$ of PCR reaction and incubate for $10 \mathrm{~min}$ at room temperature.

79. Collect the beads on a magnet and transfer $80 \mu \mathrm{L}$ of the small DNA-containing supernatant to a new tube. Discard (or keep for size determination) the SpeedBeads containing the large DNA fragments.

The DNA bound to the SpeedBeads can be washed and eluted as described in Steps 70-74.

80. To the supernatant, add $2 \mu \mathrm{L}$ of fresh SpeedBead suspension and $12 \mu \mathrm{L}$ of $20 \% \mathrm{PEG} / 2.5 \mathrm{M} \mathrm{NaCl}$ (final concentration, 8.5\% PEG). Precipitate for $5 \mathrm{~min}$ at room temperature.

81. Wash twice with $180 \mu \mathrm{L}$ of $80 \% \mathrm{EtOH}$ and elute the DNA from the beads with $20 \mu \mathrm{L}$ of TT buffer as described in Steps 70-74.

\section{(Optional) Analyzing Control Samples}

\section{Analyzing Control DNA}

For troubleshooting purposes, a fraction of the sample can be kept where indicated, the DNA processed, and checked on a gel. To rapidly isolate the DNA from the control samples, RNA and proteins are degraded in the presence of $0.5 \%$ SDS, cross-links are reversed, and the DNA is precipitated with high levels of PEG 8000 onto SpeedBeads in the presence of a low $\mathrm{NaCl}$ concentration, which prevents precipitation of the SDS.

82. Add $40 \mu \mathrm{L}$ of DNA Isolation Buffer each to the Input and Digestion Control samples. Mix, briefly centrifuge, and incubate for $15 \mathrm{~min}$ at $37^{\circ} \mathrm{C}$ in a thermal cycler.

83. Add $1 \mu \mathrm{L}$ of proteinase $\mathrm{K}\left(20 \mu \mathrm{g} / \mu \mathrm{L}\right.$ stock) to each sample. Mix and incubate for $15 \mathrm{~min}$ at $55^{\circ} \mathrm{C}$ followed by $30 \mathrm{~min}$ at $65^{\circ} \mathrm{C}$ in a thermal cycler.

84. Prepare a master mix containing $2.2 \mu \mathrm{L}$ of SpeedBeads and $52.8 \mu \mathrm{L}$ of $20 \%$ PEG 8000/1.5 $\mathrm{M} \mathrm{NaCl}$ per sample. Add $50 \mu \mathrm{L}$ of this master mix to each of the Input and Digestion control samples. Mix by vortexing for $10 \mathrm{sec}$ and incubate at room temperature for $10 \mathrm{~min}$.

85. Collect the beads on a magnet, aspirate the supernatant, and wash the beads twice with $180 \mu \mathrm{L}$ of $80 \% \mathrm{EtOH}$ as described in Step 70.

86. Aspirate the supernatant and air-dry the beads until cracks appear.

87. Resuspend the beads in $5 \mu \mathrm{L}$ of TT buffer.

88. Check the size distribution of all Control samples on a TapeStation or BioAnalyzer.

If using more than 35,000 cells total, more than $10 \mathrm{ng}$ DNA are expected per Control sample ( $\sim 4 \%$ of total), and their DNA size distribution can be checked on an agarose gel. Add $0.5 \mu \mathrm{L}$ of $12 \times$ Loading Dye (e.g., $60 \%$ glycerol/0.05\% xylene cyanol/0.05\% Orange G), to each sample, mix, and collect the beads on magnet. Electrophorese the entire supernatant on a $1 \%$ agarose/TBE gel containing $1 \times$ GelGreen. The Input Control should generate a smear at the top of the gel above $20 \mathrm{~kb}$, and the Digestion Control should be a much smaller smear from 100-600 bp in average size. Proximity ligation should increase the fragment size range of the Pre-Sonication Control to up to $10 \mathrm{~kb}$, and sonication should lower the average Post-Sonication Control to $300 \mathrm{bp}$.

\section{Digesting the Final Library}

Clal digest of the final library tests whether the fill-in, blunt-end proximity ligation and bead capture yielded tandem GATC sites ("GATCGATC") at the ligation sites within the fragments, which are cleavage sites for the restriction enzyme Clal. Digestion will reduce the size of the average library fragment in libraries with this characteristic by almost half. For example, the average fragment size of a 425-bp-average library (300 bp Clal-containing insert $+125 \mathrm{bp} \mathrm{Clal-}$ less adapter) that can be cut once in every fragment will drop to $(300 / 2+125) b p=275 \mathrm{bp}$. This size drop will confirm 
I.K. Quigley and S. Heinz

that these library prep steps were successful. An example of a high-quality library and the size drop resulting from Clal digestion is shown in Figure 1.

89. Digest $50 \mathrm{ng}$ of the final library $\left(1 \mu \mathrm{L}\right.$, if starting with $10^{5}$ nuclei) in a $10-\mu \mathrm{L}$ reaction with $1 \mu \mathrm{L}$ of $10 \times$ CutSmart buffer and $1 \mu \mathrm{L}$ of ClaI $(10 \mathrm{U} / \mu \mathrm{L})$ for $30 \mathrm{~min}$ at $37^{\circ} \mathrm{C}$.

90. Electrophorese equal amounts of undigested and digested Hi-C library next to each other on a $2 \%$ agarose/TBE gel prestained with $1 \times$ GelGreen.

Problem (Step 64, Step 76): The library yield is low, has an unexpected size distribution, or does not display the expected patterning.

Solution: Analyzing the control samples (Steps 81-89) collected throughout the protocol should give an indication of which protocol step might have failed.

Problem (Step 64, Step 76): Biotin incorporation was insufficient.

Solution: Troubleshooting of biotin incorporation can be performed by analyzing the cleavability of a PCR product derived from the ligation of two interacting loci with different restriction enzymes. Fill-in and ligation of MboI-cleaved GATC sites gives rise to a double GATCGATC site, which can be cleaved by both MboI and ClaI (recognizes ATCGATC). Ligation products that can be cleaved by both must be the product of biotin-14-dATP incorporation. Products that can only be cleaved by $\mathrm{MboI}$ are likely the product of a sticky-end ligation of GATC overhangs where the fill-in failed.

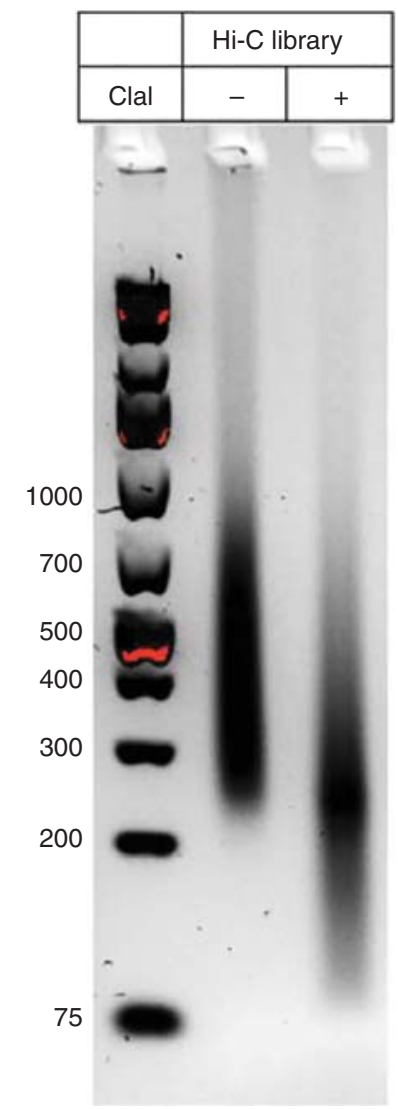

FIGURE 1. Example of a high-performing in situ Hi-C library exhibiting the expected size drop after Clal digest. 
Details on how to perform this type of troubleshooting experiment can be found in Belaghzal et al. (2017).

Problem (Step 76): Adapter dimers are present in the final library.

Solution: If despite size selection high concentrations of adapter dimers remain in the final library (visible as a $125 \mathrm{bp}$ band on the agarose gel), and if only a faint library smear in the expected $\sim 400$ bp size range is visible, one or more of the steps preceding the library preparation may have failed, and the entire experiment should be repeated.

\section{DISCUSSION}

$\mathrm{Hi}-\mathrm{C}$ is a sequencing-based method that captures $3-\mathrm{D}$ genome interactions by counting the interaction frequencies of pairs of genomic loci. Other than to characterize the 3-D organization of DNA in the nucleus, Hi-C data can be used for whole-genome sequencing and assembly, which is based on two properties of chromosomes in live cells: (1) chromosomes occupy defined territories in the nucleus, characterized by more intrachromosomal interactions than interchromosomal interactions, and (2) pairwise interaction frequencies between loci on the same chromosome decrease with linear distance. Together, these features can be exploited in order to (1) phase haplotypes, i.e., determine which alleles reside on the same chromosome, and (2) estimate chromosome assignment and the distance between sequence contigs relative to each other to improve genome-scale scaffolds (Burton et al. 2013; Kaplan and Dekker 2013; Selvaraj et al. 2013). Data generated using this protocol was used to phase the two divergent genomes of $X$. laevis and to improve its genome assembly (Fig. 2).

\section{Rules of Thumb for Sequencing Hi-C Libraries}

On the high-throughput sequencer, Hi-C libraries behave similar to large ChIP-seq libraries, clustering less efficiently due to their large size, and with a slight GATC bias at the beginning of the reads, but with an otherwise uniform sequence distribution of the inserts. Loading Hi-C libraries at $2.5 \mathrm{pm}$ on an Illumina NextSeq 500 and at 12 pm on a HiSeq 2500 resulted in excellent sequence yields and read qualities (high cluster densities and pass-filter percentages). For patterned flow cells on HiSeq $3000 / 4000$ (and NovaSeq), much higher loading concentrations (>200 pм) are required to avoid Exclusion Amplification duplicates. For de novo genome assembly, long reads will be preferred,
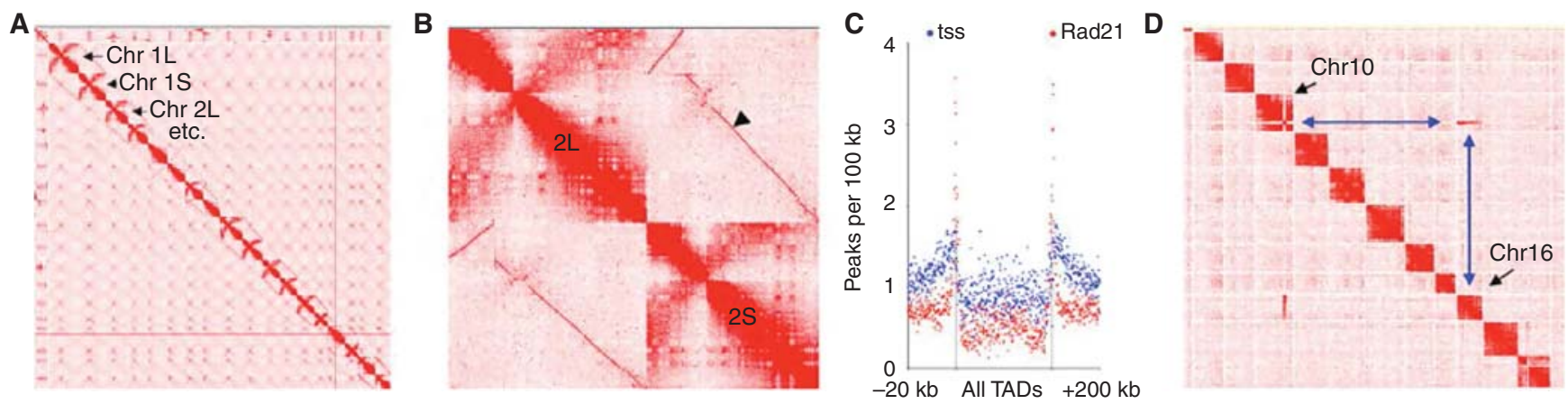

FIGURE 2. (A) Interaction matrix of $X$. laevis $\mathrm{Hi}-\mathrm{C}$, generated by the protocol described here. $X$. laevis has an allotetraploid genome, the consequence of an interspecies hybridization event, and the chromosomes are labeled with their number and "L" or "S," corresponding to "long" and "short" homologous chromosomes (Session et al. 2016). (B) Interaction matrix of $X$. laevis chromosome $2 \mathrm{~L}$ and $\mathrm{S}$. In our hands, some $0.5 \%$ of $X$. laevis $\mathrm{Hi}-\mathrm{C}$ reads map one end to the $L$ chromosome and one end to $S$, artifactually generating connections between the two chromosomes (arrowhead). (C) Metagene plot demonstrating enrichment of transcriptional start sites (tss) and Rad21 peaks at TAD boundaries. (Reprinted from Quigley and Kintner 2017). (D) Possible misassembly in the Tetraodon nigroviridis genome. We applied the protocol described here to $T$. nigroviridis tissue and observed, among others, striking interactions between chromosomes 10 and 16 (b/ue arrows), suggestive of recombination or misassembly (Jaillon et al. 2004). 
I.K. Quigley and S. Heinz

while for structure/chromosome conformation capture applications it is most economical to perform paired-end 42 cycle sequencing using 75 cycle high-output kits on a NextSeq, unless a NovaSeq is available. For initial quality assessment of a Hi-C library, 10-30 million reads are generally sufficient. In high-quality libraries, this sequencing depth will expose topological domains (TADs) and strong long-range interactions. For genome assembly with HiRise, 100 million read pairs per gigabase of genome is recommended (Putnam et al. 2016). To assemble the X. laevis genome, we used approximately 550 million read pairs (Fig. 2).

\section{Analysis of Hi-C Libraries}

To analyze 3-D genome interactions, a range of options exist for the computational processing and analysis of $\mathrm{Hi}-\mathrm{C}$ data and generating $\mathrm{Hi}-\mathrm{C}$ contact maps, and several programs allow for powerful visualization and direct browsing of interaction frequencies (see Yardımc1 and Noble [2017] for an overview). Out of these, Juicebox (https://github.com/aidenlab/Juicebox/) (Durand et al. 2016) is a comprehensive collection of tools for Hi-C analysis, as is Galaxy HiCExplorer (https://hicexplorer .usegalaxy.eu/) (Wolff et al. 2018). Both packages enable the user to do basic quality assessment, generate $\mathrm{Hi}-\mathrm{C}$ contact matrices, and call TADs and $\mathrm{A} / \mathrm{B}$ compartments. Both packages also allow the user to start from files in fastq format, directly from a sequencing run.

Alternate methods to conduct these analyses can be deployed using HOMER (Lin et al. 2012), which comes equipped with extensive, user-friendly tutorials (found at http://homer.ucsd.edu/homer/ interactions/) to perform all functions. Additionally, HOMER contains a powerful set of tools for integrating features with data from other genomic experiment types, such as ChIP-seq peaks or RNAseq, and genomic features such as TADs can be represented as peaks (e.g., bed files), allowing for easy comparison and manipulation. For example, makeMetaGeneProfile.pl, a tool included in the HOMER suite of software, can be used to show enrichment of ChIP-seq peaks at TAD boundaries (Fig. 2C).

Generating Hi-C data from understudied organisms can greatly assist in chromosome-level genome assembly (Burton et al. 2013; Putnam et al. 2016; Session et al. 2016; Dudchenko et al. 2017; Ghurye et al. 2017; Lazar et al. 2018). The basic principle underlying these approaches is that contact frequencies will increase inversely proportional to linear distance along a chromosome (along with the additional contact frequency variation that comes from DNA looping in three dimensions). These contact frequencies can be used to orient contigs and stitch together larger fragments. We have had success with HiRise (https://github.com/DovetailGenomics/HiRise_July2015_GR) (Putnam et al. 2016; Session et al. 2016), and more recent efforts have both improved on these methods computationally (https://github.com/machinegun/SALSA) (Ghurye et al. 2017) and in terms of ease-of-use (http://aidenlab.org/assembly/) (Dudchenko et al. 2017). Finally, we and others have also noticed that Hi-C data can provide evidence of chromosomal rearrangements (Chakraborty and Ay 2017; Harewood et al. 2017; Dixon et al. 2018) as well as erroneously assembled genomes (Fig. 2D).

$40 \%$ PEG 8000

\begin{tabular}{|c|c|c|}
\hline Reagent & Amount to add (for $50 \mathrm{~mL}$ ) & Final concentration \\
\hline $\begin{array}{l}\text { PEG } 8000 \text { (Sigma-Aldrich } 89510 \text { - } \\
\text { 250G-F) }\end{array}$ & $20 \mathrm{~g}$ & $40 \%(\mathrm{w} / \mathrm{v})$ \\
\hline $\mathrm{dd}_{2} \mathrm{O}$ (sterile) & Add to $50 \mathrm{~mL}$ & \\
\hline \multicolumn{3}{|c|}{$\begin{array}{l}\text { Transfer the PEG } 8000 \text { to a } 50-\mathrm{mL} \text { conical centrifuge tube and add } \mathrm{ddH}_{2} \mathrm{O} \text { to the } 50 \text { - } \mathrm{mL} \text { line. Mix } \\
\text { vigorously to suspend the PEG } 8000 \text { in the liquid and displace air in the powder. Continue mixing } \\
\text { (e.g., on a rotator) and adding } \mathrm{ddH}_{2} \mathrm{O} \text { to } 50 \mathrm{~mL} \text { until the PEG } 8000 \text { is completely dissolved. To rapidly } \\
\text { dissolve the PEG } 8000 \text {, the suspension can be briefly microwaved for no more than } 15 \mathrm{sec} \text { with the } \\
\text { unscrewed lid placed loosely on top of the conical tube. (Do not attempt to microwave the tube with } \\
\text { the lid screwed on.) To prevent gradual loss of activity due to polyether peroxidation and chain } \\
\text { shortening, store for up to } 6 \mathrm{mo} \text { at } 4^{\circ} \mathrm{C} \text { in the dark or freeze } 10 \text { - } \mathrm{mL} \text { aliquots at }-20^{\circ} \mathrm{C} \text { for long- } \\
\text { term storage. }\end{array}$} \\
\hline
\end{tabular}


BW (Bind \& Wash) Buffer (2x)

\begin{tabular}{lcr} 
Reagent & Amount to add (for $50 \mathrm{~mL})$ & Final concentration \\
\hline Tris-HCl $(1 \mathrm{M}, \mathrm{pH} 7.5)$ & $500 \mu \mathrm{L}$ & $10 \mathrm{~mm}$ \\
$\mathrm{NaCl}(5 \mathrm{M})$ & $20 \mathrm{~mL}$ & $2 \mathrm{M}$ \\
EDTA $(0.5 \mathrm{M}, \mathrm{pH} 8.0)$ & $100 \mu \mathrm{L}$ & $1 \mathrm{~mm}$ \\
ddH $_{2} \mathrm{O}$ (sterile) & $29.40 \mathrm{~mL}$ &
\end{tabular}

Store for up to $1 \mathrm{yr}$ at room temperature.

BWT (Bind \& Wash \& Tween) Buffer (2x)

\begin{tabular}{lcc} 
Reagent & Amount to add (for $50 \mathrm{~mL})$ & Final concentration \\
\hline Tris- $\mathrm{HCl}(1 \mathrm{M}, \mathrm{pH} 7.5)$ & $500 \mu \mathrm{L}$ & $10 \mathrm{~mm}$ \\
$\mathrm{NaCl}(5 \mathrm{M})$ & $20 \mathrm{~mL}$ & $2 \mathrm{M}$ \\
$\mathrm{EDTA}(0.5 \mathrm{M}, \mathrm{pH} 8.0)$ & $100 \mu \mathrm{L}$ & $1 \mathrm{~mm}$ \\
Tween $20(10 \%)$ & $1 \mathrm{~mL}$ & $0.2 \%$ \\
$\mathrm{ddH}_{2} \mathrm{O}($ sterile $)$ & $28.40 \mathrm{~mL}$ &
\end{tabular}

Store for up to $6 \mathrm{mo}$ at room temperature.

BWT100 (Bind \& Wash \& Triton X-100) Buffer (1X)

Reagent Amount to add (for $50 \mathrm{~mL}$ ) Final concentration

BW (bind \& wash) buffer $(2 \times)<\mathrm{R}>\quad 25 \mathrm{~mL} \quad 1 \times$

Triton X-100 (10\%) $\quad 500 \mu \mathrm{L} \quad 0.1 \%$

$\mathrm{ddH}_{2} \mathrm{O}$ (sterile)

$24.5 \mathrm{~mL}$

Store for up to 6 mo at room temperature.

DNA Isolation Buffer

Reagent Amount to add (for $1 \mathrm{~mL}$ ) Final concentration

Lysis Buffer for Xenopus $\mathrm{Hi}-\mathrm{C}<\mathrm{R}>$

$\mathrm{NaCl}(5 \mathrm{M})$

$909 \mu \mathrm{L}$

$66 \mu \mathrm{L}$

$330 \mathrm{~mm}$

RNase A $(10 \mu \mathrm{g} / \mu \mathrm{L})$

$25 \mu \mathrm{L}$

$250 \mathrm{ng} / \mu \mathrm{L}$

Store for up to $1 \mathrm{mo}$ at $4^{\circ} \mathrm{C}$. SDS precipitates at $4^{\circ} \mathrm{C}$; thoroughly resuspend before using the buffer after storage at $4^{\circ} \mathrm{C}$

Lysis Buffer for Xenopus Hi-C

\begin{tabular}{lcc} 
Reagent & Amount to add (for 5 mL) & Final concentration \\
\hline Tris- $\mathrm{HCl}(1 \mathrm{~m}, \mathrm{pH} 7.5)$ & $250 \mu \mathrm{L}$ & $50 \mathrm{~mm}$ \\
$\mathrm{NaCl}(5 \mathrm{M})$ & $10 \mu \mathrm{L}$ & $10 \mathrm{~mm}$ \\
EDTA $(0.5 \mathrm{M}, \mathrm{pH} 8.0)$ & $10 \mu \mathrm{L}$ & $1 \mathrm{~mm}$ \\
$\mathrm{SDS}(10 \%)$ & $280 \mu \mathrm{L}$ & $0.56 \%$ \\
$\mathrm{ddH}_{2} \mathrm{O}$ (sterile) & $4.4 \mathrm{~mL}$ &
\end{tabular}

Store for up to $1 \mathrm{yr}$ at room temperature. Add $50 \mu \mathrm{L}$ of $100 \times$ protease inhibitor cocktail (SigmaAldrich P8340) immediately before use. 
I.K. Quigley and S. Heinz

PEG $(20 \%) / 1.5$ м NaCl

\begin{tabular}{lcc} 
Reagent & Amount to add (for $50 \mathrm{~mL})$ & Final concentration \\
\hline $40 \%$ PEG $8000<\mathrm{R}>$ & $25 \mathrm{~mL}$ & $20 \%$ \\
$\mathrm{NaCl}(5 \mathrm{~m})$ & $15 \mathrm{~mL}$ & $1.5 \mathrm{M}$ \\
$\mathrm{ddH}_{2} \mathrm{O}$ (sterile) & $10 \mathrm{~mL}$ &
\end{tabular}

Store for up to $6 \mathrm{mo}$ at $4^{\circ} \mathrm{C}$.

PEG $(20 \%) / 2.5 \mathrm{M} \mathrm{NaCl}$

Reagent Amount to add (for $50 \mathrm{~mL}$ ) Final concentration

$40 \%$ PEG $8000<\mathrm{R}>\quad 25 \mathrm{~mL} \quad 20 \%$

$\mathrm{NaCl}(5 \mathrm{M}) \quad 25 \mathrm{~mL} \quad 2.5 \mathrm{M}$

Store for up to $6 \mathrm{mo}$ at $4^{\circ} \mathrm{C}$.

TE Buffer

\begin{tabular}{lcc} 
Reagent & Quantity (for $100 \mathrm{~mL})$ & Final concentration \\
\hline EDTA $(0.5 \mathrm{M}, \mathrm{pH} 8.0)$ & $0.2 \mathrm{~mL}$ & $1 \mathrm{~mm}$ \\
Tris-Cl $(1 \mathrm{M}, \mathrm{pH} 8.0)$ & $1 \mathrm{~mL}$ & $10 \mathrm{mM}$
\end{tabular}

$\mathrm{H}_{2} \mathrm{O}$

to $100 \mathrm{~mL}$

TET Buffer

TET buffer $<$ R $>$

$0.05 \%$ Tween 20

TT Buffer

\begin{tabular}{lcc} 
Reagent & Amount to add (for $50 \mathrm{~mL})$ & Final concentration \\
\hline Tris- $\mathrm{HCl}(1 \mathrm{M}, \mathrm{pH} 8.0)$ & $500 \mu \mathrm{L}$ & $10 \mathrm{mM}$ \\
Tween $20(10 \%)$ & $250 \mu \mathrm{L}$ & $0.05 \%$ \\
$\mathrm{ddH}_{2} \mathrm{O}$ (sterile) & $49.25 \mathrm{~mL}$ &
\end{tabular}

Store for up to $6 \mathrm{mo}$ at $4^{\circ} \mathrm{C}$.

\section{TTLoE Buffer}

\begin{tabular}{lcc} 
Reagent & Amount to add (for $10 \mathrm{~mL})$ & Final concentration \\
\hline Tris- $\mathrm{HCl}(1 \mathrm{M}, \mathrm{pH} 8.0)$ & $50 \mu \mathrm{L}$ & $5 \mathrm{~mm}$ \\
Tween $20(10 \%)$ & $25 \mu \mathrm{L}$ & $0.025 \%$ \\
EDTA $(0.5 \mathrm{M}, \mathrm{pH} 8.0)$ & $2 \mu \mathrm{L}$ & $0.1 \mathrm{~mm}$ \\
$\mathrm{ddH}_{2} \mathrm{O}$ (sterile) & $9.92 \mathrm{~mL}$ &
\end{tabular}

Store for up to $6 \mathrm{mo}$ at $4^{\circ} \mathrm{C}$. 


\section{REFERENCES}

Ariizumi T, Takahashi S, Chan T-C, Ito Y, Michiue T, Asashima M. 2009. Isolation and differentiation of Xenopus animal cap cells. Curr Protoc Stem Cell Biol Chapter 1: Unit 1D.5. doi:10.1002/9780470151808 .sc01d05s9

Belaghzal H, Dekker J, Gibcus JH. 2017. Hi-C 2.0: an optimized Hi-C procedure for high-resolution genome-wide mapping of chromosome conformation. Methods 123: 56-65. doi:10.1016/j.ymeth.2017.04.004

Burton JN, Adey A, Patwardhan RP, Qiu R, Kitzman JO, Shendure J. 2013. Chromosome-scale scaffolding of de novo genome assemblies based on chromatin interactions. Nat Biotechnol 31: 1119-1125. doi:10.1038/nbt .2727

Chakraborty A, Ay F. 2017. Identification of copy number variations and translocations in cancer cells from Hi-C data. Bioinformatics doi:10 .1093/bioinformatics/btx664.

Dekker J, Rippe K, Dekker M, Kleckner N. 2002. Capturing chromosome conformation. Science 295: 1306-1311. doi:10.1126/science.1067799

Dixon JR, Xu J, Dileep V, Zhan Y, Song F, Le VT, Yardımcı GG, Chakraborty A, Bann DV, Wang Y, et al. 2018. Integrative detection and analysis of structural variation in cancer genomes. Nat Genet 50: 1388-1398. doi:10.1038/s41588-018-0195-8

Dudchenko O, Batra SS, Omer AD, Nyquist SK, Hoeger M, Durand NC Shamim MS, Machol I, Lander ES, Aiden AP, et al. 2017. De novo assembly of the Aedes aegypti genome using $\mathrm{Hi}-\mathrm{C}$ yields chromosome-length scaffolds. Science 356: 92-95. doi:10.1126/science.aal3327

Durand NC, Robinson JT, Shamim MS, Machol I, Mesirov JP, Lander ES, Aiden EL. 2016. Juicebox provides a visualization system for Hi-C contact maps with unlimited zoom. Cell Syst 3: 99-101. doi:10.1016/j .cels.2015.07.012

Ghurye J, Pop M, Koren S, Bickhart D, Chin C-S. 2017. Scaffolding of long read assemblies using long range contact information. BMC Genomics 18: 527. doi:10.1186/s12864-017-3879-z

Harewood L, Kishore K, Eldridge MD, Wingett S, Pearson D, Schoenfelder S, Collins VP, Fraser P. 2017. Hi-C as a tool for precise detection and characterisation of chromosomal rearrangements and copy number variation in human tumours. Genome Biol 18: 125. doi:10.1186/ s13059-017-1253-8

Jaillon O, Aury J-M, Brunet F, Petit J-L, Stange-Thomann N, Mauceli E, Bouneau L, Fischer C, Ozouf-Costaz C, Bernot A, et al. 2004. Genome duplication in the teleost fish Tetraodon nigroviridis reveals the early vertebrate proto-karyotype. Nature 431: 946-957. doi:10.1038/ nature 03025

Kaplan N, Dekker J. 2013. High-throughput genome scaffolding from in vivo DNA interaction frequency. Nat Biotechnol 31: 1143-1147. doi:10 $.1038 /$ nbt. 2768

Lazar NH, Nevonen KA, O'Connell B, McCann C, O’Neill RJ, Green RE, Meyer TJ, Okhovat M, Carbone L. 2018. Epigenetic maintenance of topological domains in the highly rearranged gibbon genome. Genome Res 28: 983-997. doi:10.1101/gr.233874.117
Liang Z, Li G, Wang Z, Djekidel MN, Li Y, Qian M-P, Zhang MQ, Chen Y. 2017. BL-Hi-C is an efficient and sensitive approach for capturing structural and regulatory chromatin interactions. Nat Commun 8: 1622. doi:10.1038/s41467-017-01754-3

Lieberman-Aiden E, van Berkum NL, Williams L, Imakaev M, Ragoczy T, Telling A, Amit I, Lajoie BR, Sabo PJ, Dorschner MO, et al. 2009. Comprehensive mapping of long-range interactions reveals folding principles of the human genome. Science 326: 289-293. doi:10.1126/ science. 1181369

Lin YC, Benner C, Mansson R, Heinz S, Miyazaki K, Miyazaki M, Chandra V, Bossen C, Glass CK, Murre C. 2012. Global changes in the nuclear positioning of genes and intra- and interdomain genomic interactions that orchestrate B cell fate. Nat Immunol 13: 1196-1204. doi:10.1038/ni .2432

Mishra A, Hawkins RD. 2017. Three-dimensional genome architecture and emerging technologies: looping in disease. Genome Med 9: 87. doi:10 .1186/s13073-017-0477-2

Nickerson JA, Krockmalnic G, Wan KM, Penman S. 1997. The nuclear matrix revealed by eluting chromatin from a cross-linked nucleus. Proc Natl Acad Sci 94: 4446-4450. doi:10.1073/pnas.94.9.4446

Putnam NH, O'Connell BL, Stites JC, Rice BJ, Blanchette M, Calef R, Troll CJ, Fields A, Hartley PD, Sugnet CW, et al. 2016. Chromosome-scale shotgun assembly using an in vitro method for long-range linkage. Genome Res 26: 342-350. doi:10.1101/gr.193474.115

Quigley IK, Kintner C. 2017. Rfx2 stabilizes Foxj1 binding at chromatin loops to enable multiciliated cell gene expression. PLoS Genet 13: e1006538. doi:10.1371/journal.pgen.1006538

Rao SSP, Huntley MH, Durand NC, Stamenova EK, Bochkov ID, Robinson JT, Sanborn AL, Machol I, Omer AD, Lander ES, et al. 2014. A 3D map of the human genome at kilobase resolution reveals principles of chromatin looping. Cell 159: 1665-1680. doi:10.1016/j.cell.2014.11.021

Selvaraj S, Dixon JR, Bansal V, Ren B. 2013. Whole-genome haplotype reconstruction using proximity-ligation and shotgun sequencing. Nat Biotechnol 31: 1111-1118. doi:10.1038/nbt.2728

Session AM, Uno Y, Kwon T, Chapman JA, Toyoda A, Takahashi S, Fukui A, Hikosaka A, Suzuki A, Kondo M, et al. 2016. Genome evolution in the allotetraploid frog Xenopus laevis. Nature 538: 336-343. doi:10.1038/ nature 19840

Sive HL, Grainger RM, Harland RM. 2010. Early development of Xenopus laevis: a laboratory manual. Cold Spring Harbor Laboratory Press, Cold Spring Harbor, NY.

Wolff J, Bhardwaj V, Nothjunge S, Richard G, Renschler G, Gilsbach R, Manke T, Backofen R, Ramírez F, Grüning BA. 2018. Galaxy HiCExplorer: a web server for reproducible $\mathrm{Hi}-\mathrm{C}$ data analysis, quality control and visualization. Nucleic Acids Res 46: W11-W16. doi:10.1093/nar/gky504

Yardımcı GG, Noble WS. 2017. Software tools for visualizing Hi-C data. Genome Biol 18: 26. doi:10.1186/s13059-017-1161-y 


\section{Generating a Three-Dimensional Genome from Xenopus with Hi-C}

lan K. Quigley and Sven Heinz

Cold Spring Harb Protoc; doi: 10.1101/pdb.prot098343 originally published online March 18, 2019

\begin{tabular}{|c|c|}
\hline $\begin{array}{r}\text { Email Alerting } \\
\text { Service }\end{array}$ & Receive free email alerts when new articles cite this article - click here. \\
\hline $\begin{array}{l}\text { Subject } \\
\text { Categories }\end{array}$ & $\begin{array}{l}\text { Browse articles on similar topics from Cold Spring Harbor Protocols. } \\
\text { DNA Sequencing (97 articles) } \\
\text { Genome Analysis (191 articles) } \\
\text { Genomic DNA (135 articles) } \\
\text { Genomic Libraries (66 articles) } \\
\text { High-Throughput Analysis, general (155 articles) } \\
\text { Libraries (147 articles) } \\
\text { Molecular Biology, general (1293 articles) } \\
\text { Xenopus (210 articles) }\end{array}$ \\
\hline
\end{tabular}

